\title{
MEASURING PEER FEEDBACK ON WRITING CLASS: A STUDY ON THIRD-SEMESTER PRE-SERVICE ENGLISH TEACHERS
}

\author{
Didik Rinan Sumektoㅜ; Heny Setyawati² \\ ${ }^{1}$ English Education Department, Widya Dharma University, Klaten \\ Jl. Ki Hajar Dewantara, Klaten Utara, Klaten 57438, Indonesia \\ ${ }^{2}$ Physical Education Departement, Sports Science Faculty, Semarang State University \\ Gedung F3, Lantai 1, Kampus Sekaran Gunungpati, Semarang 50229, Indonesia \\ 1'didikrinan@unwidha.ac.id; ${ }^{2 h}$ nenysetyawati@mail.unnes.ac.id
}

Received: $12^{\text {th }}$ December 2018/Revised: $19^{\text {th }}$ February 2019/Accepted: $26^{\text {th }}$ February 2019

How to Cite: Sumekto, D. R., \& Setyawati, H. (2019). Measuring peer feedback on writing class:

A study on third-semester pre-service English teachers. Lingua Cultura, 13(1), 45-53.

https://doi.org/10.21512/lc.v13i1.5058

\begin{abstract}
This research aimed to measure the contributions of students' peer feedback set in the collaborative writing class. Of 144 population, 55 undergraduate English education students were involved as the participants in a quasi-experimental research design which was conducted through a non-randomized five experimental and five control groups. There were 25 experimental participants attended in the regular classes with the collaborative writing class syntax, namely; genres selection, problembased learning, genres, and peer feedback practices, while other 30 control participants naturally attended in the same activity. Data were collected through the collaborative writing's pre- and post-test, and peer feedback instruments within four weeks of the lectures. Data analysis used the Mann-Whitney U, and Wilcoxon signed rank tests. The findings show that the collaborative writing's peer feedback positively contributes to students' writing skills and learning awareness resulted in the post-tests. Peer feedback may correct students' writing mistakes and contribute a significant difference between the experimental and control groups $(Z=-2,471 ; p \leq 0,05)$. Peer feedback socially tightens students' collaborative writing and promotes a mutual relationship among group members, and reduces lecturer's feedback.
\end{abstract}

Keywords: peer feedback, collaborative writing, problem-solving competence

\section{INTRODUCTION}

A paradigm shift has changed in the second language (L2) learning where the focus is absolutely no longer on a lecture-based interaction, but rather than students' interaction with peers. The interaction addresses students' opportunities for conducive L2 writing practice, the feedback exchange to facilitate the peer assistance (Yu, 2015), and to require an appropriate understanding of how the collaborative communication provides the L2 students with group works' opportunity (Ciftci \& Kocoglu, 2012) through the peer feedback. This feedback produces an active-constructive-interactive process and Vygotsky's zone of proximal development concept (Lin \& Yang, 2011) that have been critical to the enhanced learning, deep conceptual understanding (Comer, Clark, \& Canelas, 2014), stimulated broad-mindedness, and cognitive maturity among students.

Further, peer feedback substantially helps the writers to identify and avoid errors (Lei, 2017). The feedback can be contextually exemplified towards the genre-based paragraphs for its genuine interaction availability and function like providing more practices that stimulated the peer feedback of the collaborative writing. Sumekto (2017) have pointed out that collaborative writing accommodates any procedural problem-solving, enhances, and improves language use. It is expected that the number of poor writings is reduced and the flow of improved paragraphs increase (Chen, Chung, \& Wu, 2013) after having collaboration. This confers linguistic acquisition abilities, including grammatical accuracy, lexicon, syntax, organization, style, and rhetoric strategies (Ahangari \& Babapour, 2015). It is as well as the punctuation errors reduction and the identifiable thesis statements increases between a draft to a final submission (Leydon, Wilson, \& Boyd, 2014).

These linguistic acquisition abilities are potentially stimulated through promoted collaboration. Unfortunately, the higher education students seldom gain an opportunity to write better since their large classes make the lecturer difficult to provide adequate peer feedback's writing assessment (Arum \& Roksa, 2011; Patchan et al., 2013). On a firm situation, peers are sometimes unwilling to be critical and unable to point out all errors found in writings (Liu \& Chai, 2009). However, in this respect, the peer feedback has attempted to put in the L2 writing from the effectiveness 
perspectives and has exerted an increasing influence on the writing instruction (Lai, 2010), as the activity promises to encourage negotiation and construction as well as to help students develop new perspectives on the writing paragraphs (Lin \& Yang, 2011).

In particular, Sumekto and Setyawati (2018) have empirically portrayed that well-formatted writing widely starts from the title which is displayed at the beginning of the writing part. The title shall be centered and commonly typed with a capital letter for the first letter. When writing a new paragraph, the first sentence is intended with three to five characters before writing the second paragraph with the double-space.

The constructive support for the use of peer feedback has transcended from relevant theories and experiences in collaborative writing. The peer feedback effectively allows students to construct knowledge (Taylor, 2014), to give students the sense of holding audiences, to encourage a collaborative dialog, and to be less formal and more accessible (Nguyen, 2012). It can be done by providing comments on others' writing and catalyzing a social space for communication and discussion (Lin \& Yang, 2011), clear guidelines, modeling, and frequent opportunities to engage in guided practice (Lenters \& Grant, 2016), as well as creating a facilitation upon the interactive environment $(\mathrm{Hu}$ \& Lam, 2010). Another support leads to creating a friendly and relaxed atmosphere in the collaborative writing classes that engage the language acquisition techniques (Ahangari \& Babapour, 2015).

Peer feedback has been recognized as the basic element to support students' interaction processes and involves a reciprocal communication process related to the performance and standards (Gan \& Hattie, 2014). The peer feedback is welcomed by students (Nguyen, 2012) to develop the critical reflection (Ekş̌̌, 2012), show sense of accountability, motivation, and responsibility (Bloxham \& Boyd, 2007), promote learners' writing accuracy, offer the opportunities to share ideas, give comments, and suggestions and maximizes motivation (Ahangari \& Babapour, 2015). This feedback can be a substitute for lecturer's feedback (Gielen et al., 2010; Hu \& Lam, 2010; Gardner, 2006) to enhance students' independent problem-solving capacity.

Peers are convinced to yield improvements in the collaborative writing that are significantly higher than improvements for those who receive assessment from the lecturer (Kaufman \& Schunn, 2011). This feedback can also reduce errors and it has positive effects on increasing students' writing skills when received thoughtfully and positively, as well as being essential to the development and execution of self-regulatory skills (Topping, 2009). Alternatively, students have opportunities to involve themselves in the direct assessment activity and be more active participants (Philpott, 2009).

On the other hand, the theoretical gap on the peer feedback potentially leads to the over-emphasis on the added value for either the receivers or the providers since it might result in a limited understanding as a two-way process (Van Popta et al., 2017). Shortly, Wakabayashi (2013) has concluded that the peer negotiation as a part the peer feedback's typical component may not be included in the procedure. So, the deviation between reviewing-peertexts and reviewing one's own texts are differently rated. For example, the number of marks gained on drafts is 0,812 , the comments and marks accuracy are 0,720 , and the proportion of groups' specific comments are 0,173. All these aspects are not significantly different at the level of 0,05
(Ruegg, 2014).

Further, peer feedback is not always being encouraged in the best interest of reflecting the intellectual capacity or seeking the truth to some minor peers (Roberts \& Shambrook, 2012). Altstaedter and Doolittle (2014) have pointed out that students' perception qualitatively has reported a more general aspect of feedback on the organization and idea development, rather than a particular aspect of feedback on grammar and mechanics. This performance, according to (McGrath, Taylor, and Pychyl (2011), empirically contributes that the writing feedback has significantly affected students' perceptions that relate to the higher ratings of fairness and helpfulness, but it does not have a significant effect on their writing performance.

Some researches on writing's peer feedback empirically have been carried out in the classroom. It measures students' academic performance which accordingly resulted in pre- and post-test aspects, namely content, vocabulary, grammar, and mechanics (Arslan, 2014). However, the suggestive feedback is closely correlated to the collaborative learning engagement, where $F(3,197)=15,714 ; p<0,001$ (Guasch et al., 2013). The feedback is effective and playing a positive role and attitude in stimulating and improving students' academic achievement. Students who have low writing proficiency could enhance while collaboratively working with a peer and comment on the drafts through the discussion (Ghani \& Asgher, 2012). A majority of students appreciate some comments regarding peer feedback (Chen, Chung, \& Wu, 2013).

Meanwhile, Chen et al. (2011) have reported that $53 \%$ of writing's feedback activity enables students to drive the appropriate responses. Peer-to-peer writing interactions through the forums and peer feedback enhance to understand, link to the learning objectives, and positively contribute to the learning environment (Comer, Clark, \& Canelas, 2014). Peer feedback contributes to students' autonomy in which they might write their final drafts relying on one another and without seeking for lecturer's assistance at each stage (Ekş̌̌, 2012).

The feedback elements might be an instructional strategy to promote active critical engagement with the scientific text and issues. The extensions of peer feedback have significant longer-term learning effects, in which the raters provide more useful feedback when informed to the test-takers' questions and doubts beforehand (Gan \& Hattie, 2014). Shortly, in a certain position of peer feedback groups, approximately 37 to $38 \%$ of the participants receive this feedback as assistance (Gielen et al., 2010). Hu and Lam (2010) have pointed out that after the drafts are revised on the basis of the peer feedback, the writing quality might improve significantly either in terms of overall quality or in terms of the language, content, and organization. Further, Yu, Lee, and Mak (2016) have recorded the diversity and individual differences in students' beliefs and practices in peer feedback for L2 writing. Students share similar linguistic and cultural backgrounds and are situated in a similar learning context of classroom and group. These differences guide students to reflect on their participation in peer feedback.

Some of the peer's expertise is not in language background. Their advice might be fully correct or incorrect and sometimes even misleading. Peers are not regarded as being knowledge authorities; consequently, they are reluctant to accept peers' advice or vice versa (Strijbos, Narciss, \& Dünnebier, 2010; Jiang \& Yu, 2014). For instance, the 
scoring rubric that is used in the writing-based assessments might constitute the organization, mechanics, evidence, and sentence structure (Prastika, Setiawati, \& Sumekto, 2018). However, the ratio of peers' correction acceptance is still very low because peers take part in non-correctionoriented practices, such as casual social communication with others, usually expressed the appreciative words rather than put the correction-oriented notes like critical comments, clarifications, and constructive feedback (Liou \& Peng, 2009; Jiang \& Yu, 2014). Thus, peer feedback does not always lead students to rightly revise their writing because of the useful and effective feedback is not generally revealed (Tsui \& Ng, 2000; Jiang \& Yu, 2014).

Some weaknesses of the peer feedback also rely on both the processes and outcomes that might not be immediately manifested but rather than emerged and intensified with experience as students' fears of others' selfenhancing biases (Bamberger et al., 2005) and even have not enough trust to the peer's accurateness, honesty, and explicitness (Ferris, 1997). Further, Ferris and Hedgcock (2005) have believed that peer feedback's problems appear among students since they only specifically concern with the surface editing while ignoring the substantial revisions. Some possibly provide vaguely, complicate comments, besides being negative, sarcastic, overly critical, or unkind in the criticisms of their peer's writing.

Lack of L2 formal schemata also address the inappropriate expectations regarding the content and structure of peers' texts. This situation potentially leads to counter-productive feedback. Referring to this situation, as if students spend many times, energies, and efforts working with the peer feedback in order to gain their qualifications as better writers, whereas the satisfactory results have not been confidently progressed (Mooney, 2004). However, the gap of the peer feedback activity leads to some benefits and weaknesses when being implemented in collaborative writing in the classroom. Both benefits and weaknesses potentially contribute to undergraduate students' academic and non-academic skills to support their peer feedback necessities.

Being conscious of the facts, this research objective aims to measure the contributions of students' peer feedback that is designed in the collaborative writing class. This learning design mobilizes five members in a group of undergraduate students through the peer feedback practices that engage students' academic and non-academic contexts. By measuring students' pre- and post-tests of the collaborative writing, hence, this research puts the insightful peer feedback impacts and the collaborative writing lectures that facilitate how the undergraduate students in the small groups interact within the natural collaborative writing class.

Thus, peer feedback is analyzed in terms of the following research questions (RQs): RQ1 - Do pre- and post-tests influence the collaborative writing's peer feedback significantly? RQ2 - Do the experimental and control group members perceive that peer feedback is helpful to bridge the learning awareness and encourage students' collaborative writing skills?

\section{METHODS}

This research applies for a quasi-experimental design (Creswell, 2005) that conducted students' pre- and post-test through the collaborative writing class. This design purposefully uses non-randomized experimental and control groups. Of 144 undergraduate English education students of Sarjanawiyata Tamansiswa University, Yogyakarta, Indonesia, 55 third-semesters of the students are engaged to be the research participants. The participants are classified into five groups, and each group consists of five members. In this research design, 25 participants included in the experimental group by attending the collaborative writing class syntax, such as understanding genres selection, prioritizing problem-based learning, and practicing with genres and peer feedback. Meanwhile, the other 30 participants participate as the control group.

The peer feedback procedure is started with the recount, narrative, and descriptive paragraphs which are connected with the problem-based learning. It approximately undertakes 20 minutes before ending the collaborative writing session. Participants are set in a permanent groupin-stage of their learning circumstances to obtain the collaborative writing's peer feedback preferences. The first stage involves students to work with the individual writing trials as a draft and then is followed by the reciprocal peer feedback and revisions. The second stage is begun with students' revised writing (first and second draft), prior to implementing experiments, collecting and analyzing sentences into paragraphs, and finally writing complete paragraphs (e.g., recount, narrative, and descriptive).

These activities are then continued with the additional turn and cross of the peer feedback exchanges and revisions before the submission stage of individuals' final best paragraphs are undertaken. The rubric was modified from Pappamihiel, Nishimata, and Mihai (2008). After receiving revisions and brief comments, each peer is rated a set of revisions and comments on other writings.

Data collection uses the collaborative writing's preand post-tests, and the peer feedback instruments to match with the assessment practice engaged in collaborative writing. Data analysis uses non-parametric statistics that focuses on the Mann-Whitney U and Wilcoxon signed rank tests using the IBM SPSS 20 software.

\section{RESULTS AND DISCUSSIONS}

The 25 participants in the experimental group undertake the pre- and post-tests that corresponded with the recount, narrative, and descriptive paragraphs. As shown in Table 1, the paired-samples of these paragraphs show an improvement, where the mean increases from 70,51 to 73,26 for the recount $(M=2,744 ; S D=1,347 ; t=1,347 ; p$ $=0,000), 71,58$ to 74,35 for the narrative $(M=2,767 ; S D$ $=1,771 ; t=10,249 ; p=0,000)$, and 71,07 to 74,56 for the descriptive paragraphs $(M=3,488 ; S D=1,594 ; t=14,349$; $p=0,000)$ with the correlation coefficients, $r=0,30$; $p<0,05$. The statistical results analyze that the peer feedback conveys a broader facet after addressing a determination in the peer interaction by the raters. The reasons reflect the problem-solving among the participants and consider the creativity factors on learning behavior and difficulty level, and organization during the collaborative writing classes.

The peer feedback is conditionally adaptive, effective, and suitable to improve the collaborative writing skills with the instructional evaluation consequences. These consequences are filed in the Mann-Whitney U tests. The results show an improvement in both groups. Statistically, the experimental groups increase the recount $(Z=-5,230$; $p<0,01)$, the narrative $(Z=-5,232 ; p<0,01)$, and the 
descriptive paragraphs $(Z=-5,230 ; p<0,01)$, whereas the control groups show that the recount $(Z=-5,531 ; p<0,05)$, the narrative $(Z=-5,433 ; p<0,05)$, and the descriptive paragraphs $(Z=-5,631 ; p<0,05)$. The $Z$ value does not show a different significantly between the experimental and control group when determining the peer feedback practices. This deals with the learning behavior, in which the collaborative writing and the social interaction affairs are referred to the constructive learning mechanism among the group members.

Further, the Wilcoxon signed rank tests summarize the learning objectives of the recount, narrative, and descriptive paragraphs (Table 2). The results indicate a significant correlation $(p<0,01)$, which increase the writing skills after implementing the collaborative writing's peer feedback.

On the other hand, the Mann-Whitney U tests correspond with the collaborative writing's peer feedback setting. As shown in Table 3, both the experimental and control groups regard their feedback involvement and have an influence on the writing class environments. The peer feedback constitutes 11 items to be designed as the variables. Of 11 items, merely one variable determines that the peer feedback criticized the works and corrected mistakes ( $\mathrm{Z}$ $=-2,471 ; p \leq 0,05)$. It has a significant difference both the experimental and control groups when the peer feedback is implemented.
Other 10 variables are: the peer feedback is fair enough $(Z=-0,843 ; p>0,05)$, the students understand the learning measurement $(Z=-0,519 ; p>0,05)$, the peer feedback motivates and creates esprit de corps $(Z=-1,649$; $p>0,05)$, the peer feedback reduces lecturer's subjectivity $(\mathrm{Z}=-0,054 ; p>0,05)$, the peer feedback accommodates self-responsibilitys $(Z=-1,257 ; p>0,05)$, the peer feedback is more desirable than lecturer's feedback $(Z=-1,930$; $p>0,05)$, the peer feedback assists individual learner's competence $(Z=-1,009 ; p>0,05)$, the peer feedback is enjoyable, flexible, and relaxed to conduct $(Z=-0,088$; $p>0,05)$, the peer feedback assists other peers in problemsolving $(Z=-0,516 ; p>0,05)$, and practice availability is short $(Z=-1,247 ; p>0,05)$. All of them are not significantly different from both experimental and control groups in feedback's involvement.

Being examined through the collaborative writing's peer feedback accordingly, the experimental group's recount, narrative, and descriptive paragraphs indicate its improvement through the pre- and post-test shown in Table 4. The recount's pre-test is $37,51(Z=-1,077)$, post-test is 4,19 $(Z=-2,779)$, and its gain is $55,18(-5,338)$. Then, narrative's pre-test is $36,47(Z=1,455)$, post-test is $50,86(Z=-3,741)$, and its gain is $53,73(4,782)$. Meanwhile, the descriptive pretest is $36,16(Z=-1,565)$, post-test is $47,03(Z=-2,353)$, and its gain is $52,89(-4,483)$. Conversely, the Mann-Whitney $U$ tests indicate the experimental groups' collaborative writing

Table 1 Experimental Students' Pre- and Post-Tests

\begin{tabular}{|c|c|c|c|c|c|c|c|c|c|}
\hline \multirow[b]{2}{*}{ Paired-Samples } & \multirow[b]{2}{*}{ Peer Feedback } & \multicolumn{8}{|c|}{ T-Tests } \\
\hline & & Mean & $\mathbf{N}$ & SD & $\begin{array}{c}\text { Pearson Correlation } \\
\text { (r) }\end{array}$ & Mean & SD & $\mathbf{t}$ & Sig. \\
\hline \multirow[t]{2}{*}{ Recount } & Pre-test & 70,51 & 25 & 2,711 & & 2,744 & 1,347 & 13,361 & 0,000 \\
\hline & Post-test & 73.26 & & 2,441 & & & & & \\
\hline \multirow[t]{2}{*}{ Narrative } & Pre-test & 71,58 & 25 & 2,322 & $\mathrm{r}=0,30 ; \mathrm{p}<0,05$ & 2,767 & 1,771 & 10,249 & 0,000 \\
\hline & Post-test & 74,35 & & 2,126 & & & & & \\
\hline \multirow[t]{2}{*}{ Descriptive } & Pre-test & 71,07 & 25 & 2,685 & & 3,488 & 1,594 & 14,349 & 0,000 \\
\hline & Post-test & 74,56 & & 2,423 & & & & & \\
\hline
\end{tabular}

Table 2 Wilcoxon Tests upon Three Different Paragraphs

\begin{tabular}{lllcccc}
\hline \multirow{2}{*}{ Genre } & \multicolumn{1}{c}{ Group } & \multicolumn{3}{c}{ Rank } & \multicolumn{2}{c}{ Statistics } \\
\cline { 2 - 6 } & & $\mathbf{N}$ & Mean Rank & Sum of Ranks & Wilcoxon W & $\mathbf{Z}$ \\
\hline Recount & Experiment & 25 & 18,00 & 602,00 & 1187,500 & $-5,230$ \\
& Control & 30 & 21,00 & 835,00 & & $-5,531$ \\
& Total & 55 & & & & \\
\multirow{5}{*}{ Narrative } & Experiment & 25 & 18,00 & 612,00 & 1142,000 & $-5,232$ \\
& Control & 30 & 21,00 & 715,00 & & $-5,433$ \\
& Total & 55 & & & & \\
\multirow{5}{*}{ Descriptive } & Experiment & 25 & 18,00 & 603,00 & 1372,000 & $-5,230$ \\
& Control & 30 & 21,00 & 846,00 & & $-5,631$ \\
& Total & 55 & & & & \\
\hline
\end{tabular}

Note: Significance level at $p<0,01 ; p<0,05$ 
achievement through the content, organization, vocabulary, grammar, and mechanic components.

The discussion on the peer feedback is practiced to fulfill alternative feedback accountability associated with the problem-based solution. The experimental group of peer feedback is delivered in the regular classes. The learning management scenario is collaboratively designed. Each group consists of five members who conditionally work with this feedback. The group members individually assess and are assessed with oral and written peer feedback relating to the recount, narrative, and descriptive paragraphs as the substance of the problem-solving activities. This feedback relies on the assessment form which accomplishes the students' equal performance, even it does not contribute to the rater's final grade and has a qualitative output (Gielen et al., 2010).

In further, the peer feedback engages the reflective criticism of other students' products and provides feedback, commonly using previously defined criteria through the rubric (Guasch et al., 2013). The contributing results

Table 3 Mann-Whitney U Tests' Peer Feedback Involvement

\begin{tabular}{|c|c|c|c|c|c|c|c|}
\hline \multirow[b]{2}{*}{ Variable } & \multirow[b]{2}{*}{ Group } & \multicolumn{3}{|c|}{ Rank } & \multicolumn{3}{|c|}{ Statistics } \\
\hline & & $\mathbf{N}$ & $\begin{array}{l}\text { Mean } \\
\text { Rank }\end{array}$ & $\begin{array}{l}\text { Sum of } \\
\text { Ranks }\end{array}$ & $\begin{array}{c}\text { Mann- } \\
\text { WhitneyU }\end{array}$ & WilcoxonW & $\mathbf{Z}$ \\
\hline \multirow[t]{3}{*}{ Peer feedback was fair enough } & Experiment & 25 & 36,67 & 990,00 & 522,000 & 1425,000 & $-0,843 * *$ \\
\hline & Control & 30 & 33,93 & 1425,00 & & & \\
\hline & Total & 55 & & & & & \\
\hline \multirow{3}{*}{$\begin{array}{l}\text { Students understood the learning } \\
\text { measurement }\end{array}$} & Experiment & 25 & 36,28 & 979,50 & 532,500 & 1435,500 & $-0,519 * *$ \\
\hline & Control & 30 & 34,18 & 1435,50 & & & \\
\hline & Total & 55 & & & & & \\
\hline \multirow{3}{*}{$\begin{array}{l}\text { Peer feedback criticized the works } \\
\text { and corrected mistakes }\end{array}$} & Experiment & 25 & 29,44 & 795,00 & 417,500 & 795,000 & $-2,471 * * *$ \\
\hline & Control & 30 & 38,57 & 1620,00 & & & \\
\hline & Total & 55 & & & & & \\
\hline \multirow{3}{*}{$\begin{array}{l}\text { Peer feedback motivated and cre- } \\
\text { ated esprit de corps }\end{array}$} & Experiment & 25 & 38,78 & 1047,00 & 465,000 & 1368,000 & $-1,649 * *$ \\
\hline & Control & 30 & 32,57 & 1368,00 & & & \\
\hline & Total & 55 & & & & & \\
\hline \multirow{3}{*}{$\begin{array}{l}\text { Peer feedback reduced lecturer's } \\
\text { subjectivity }\end{array}$} & Experiment & 25 & 34,89 & 942,00 & 564,000 & 942,000 & $-0,054 * *$ \\
\hline & Control & 30 & 35,07 & 1473,00 & & & \\
\hline & Total & 55 & & & & & \\
\hline \multirow{3}{*}{$\begin{array}{l}\text { Peer feedback accommodated self- } \\
\text { responsibility }\end{array}$} & Experiment & 25 & 38,06 & 1027,50 & 484,500 & 1387.500 & $-1,257 * *$ \\
\hline & Control & 30 & 33,04 & 1387,50 & & & \\
\hline & Total & 55 & & & & & \\
\hline \multirow{3}{*}{$\begin{array}{l}\text { Peer feedback was more desirable } \\
\text { than lecturer's feedback }\end{array}$} & Experiment & 25 & 37,61 & 1015,50 & 496,500 & 1399,500 & $-1,930 * *$ \\
\hline & Control & 30 & 33,32 & 1399,50 & & & \\
\hline & Total & 55 & & & & & \\
\hline \multirow{3}{*}{$\begin{array}{l}\text { Peer feedback assisted individual } \\
\text { learner's competence }\end{array}$} & Experiment & 25 & 37,22 & 1005,00 & 507,000 & 1410,000 & $-1,009 * *$ \\
\hline & Control & 30 & 33,57 & 1410,00 & & & \\
\hline & Total & 55 & & & & & \\
\hline \multirow{3}{*}{$\begin{array}{l}\text { Peer feedback was enjoyable, flex- } \\
\text { ible, and relaxed to conduct }\end{array}$} & Experiment & 25 & 34,78 & 939,00 & 561,000 & 939,000 & $-0,088 * *$ \\
\hline & Control & 30 & 35,14 & 1476,00 & & & \\
\hline & Total & 55 & & & & & \\
\hline \multirow{3}{*}{$\begin{array}{l}\text { Peer feedback assisted other peers } \\
\text { in problem-solving }\end{array}$} & Experiment & 25 & 33,89 & 915,00 & 537,000 & 915,000 & $-0,516 * *$ \\
\hline & Control & 30 & 35,71 & 1500,00 & & & \\
\hline & Total & 55 & & & & & \\
\hline \multirow[t]{3}{*}{ Practice availability was short } & Experiment & 25 & 35,78 & 966,00 & 546,000 & 1449,000 & $-1,247 * *$ \\
\hline & Control & 30 & 34,50 & 1449,00 & & & \\
\hline & Total & 55 & & & & & \\
\hline
\end{tabular}

Note: Significance level at ${ }^{* *} p>0,05 ; * * * p \leq 0,05$ 


\begin{tabular}{|c|c|c|c|c|c|c|c|}
\hline \multirow[b]{2}{*}{ Genre } & \multirow[b]{2}{*}{ Group } & \multicolumn{3}{|c|}{ Rank } & \multicolumn{3}{|c|}{ Statistics } \\
\hline & & $\mathbf{N}$ & $\begin{array}{l}\text { Mean } \\
\text { Rank }\end{array}$ & $\begin{array}{l}\text { Sum of } \\
\text { Ranks }\end{array}$ & $\begin{array}{c}\text { Mann- } \\
\text { WhitneyU }\end{array}$ & WilcoxonW & $\mathbf{Z}$ \\
\hline \multirow[t]{3}{*}{ Recount (Pre-test) } & Experiment & 25 & 37,51 & 1388,00 & 685,00 & 1457,000 & $-1,077 * * *$ \\
\hline & Control & 30 & 43,07 & 1852,00 & & & \\
\hline & Total & 55 & & & & & \\
\hline \multirow[t]{3}{*}{ Recount (Post-test) } & Experiment & 25 & 48,19 & 1783,00 & 511,000 & 1457,000 & $-2,779 * *$ \\
\hline & Control & 30 & 33,88 & 1457,00 & & & \\
\hline & Total & 55 & & & & & \\
\hline \multirow[t]{3}{*}{ Recount (Gain) } & Experiment & 25 & 55,18 & 2041,50 & 252,500 & 1198,500 & $-5,338 * *$ \\
\hline & Control & 30 & 27,87 & 1198,50 & & & \\
\hline & Total & 55 & & & & & \\
\hline \multirow[t]{3}{*}{ Narrative (Pre-test) } & Experiment & 25 & 36,47 & 1349,50 & 646,500 & 1349,500 & $-1,455 * * *$ \\
\hline & Control & 30 & 43,97 & 1890,50 & & & \\
\hline & Total & 55 & & & & & \\
\hline \multirow[t]{3}{*}{ Narrative (Post-test) } & Experiment & 25 & 50,86 & 1882,00 & 412,000 & 1358,000 & $-3,741 * *$ \\
\hline & Control & 30 & 31,58 & 1358,00 & & & \\
\hline & Total & 55 & & & & & \\
\hline \multirow[t]{3}{*}{ Narrative (Gain) } & Experiment & 25 & 53,73 & 1988,00 & 306,000 & 1252,000 & $-4,782 * *$ \\
\hline & Control & 30 & 29,12 & 1252,00 & & & \\
\hline & Total & 55 & & & & & \\
\hline \multirow[t]{3}{*}{ Descriptive (Pre-test) } & Experiment & 25 & 36,16 & 1338,00 & 635,000 & 1338,000 & $-1,565^{* * *}$ \\
\hline & Control & 30 & 44,24 & 1902,00 & & & \\
\hline & Total & 55 & & & & & \\
\hline \multirow[t]{3}{*}{ Descriptive (Post-test) } & Experiment & 25 & 47,03 & 1740,00 & 554,000 & 1500,000 & $-2,353 * *$ \\
\hline & Control & 30 & 34,88 & 1500,00 & & & \\
\hline & Total & 55 & & & & & \\
\hline \multirow[t]{3}{*}{ Descriptive (Gain) } & Experiment & 25 & 52,89 & 1957,00 & 337,000 & 1283,000 & $-4,483 * *$ \\
\hline & Control & 30 & 29,84 & 1283,00 & & & \\
\hline & Total & 55 & & & & & \\
\hline
\end{tabular}

Note: Significance level at ${ }^{* *} p \leq 0,05 ; * * * p>0,05$

address to students' peer feedback involvements during collaborative writing. These involvements summarize the reflection upon the collaborative classes which describe the learning circumstance, such as comforts and openness, suitable writing skill tasks, and lecturer's collaboration with students' learning activities. This means that the feedback provides an accomplished condition to the students, as it might improve students' posture toward writing and raise their writing confidence, as well as be an appropriate circumstance for independent learning (Ghani \& Asgher, 2012).

The collaborative writing, however, conveys an opportunity towards students' assessment involvement that accordingly supports the learning behavior and paradigm. Students are participated in conducting this assessment; they are attractive and willing to do the real works in the group especially when revising others' works which indicate some errors. The peer starts with a quick response, soon after the feedback tasks become peer ratings' responsibility. The learning circumstance is not rigid, but more democratic.
The group members work with the increased problemsolving constructively. This situation corresponds with McConlogue (2012) idea, in which he believes that students have divergent or open responses. Tasks necessitate reasoning and problem-solving that could be approached in a variety of students' perspectives and understanding about the writing assignments.

The collaborative writing's peer feedback increases students' problem-based learning and writing's pre- and post-test, which impacts to students' writing skills and social relationships, since this feedback ascertains the use of the logical framework. In this position, Gielen et al. (2010); Ciftci and Kocoglu (2012); Khorasani and Sadzadeh (2015) have agreed that the peer feedback has impacted the positive influences in the L2 writing class. This feedback puts more control and autonomy to the English education students to be actively involved during the process. The interaction gains a sense of meaningfulness, although the practices are not easily parted from the previous weaknesses. To eliminate these weaknesses, the peer feedback might be regularly 
well-practiced and increasingly used it in instructional settings, beyond the specific focus on the collaborative writing's feedback (Nelson \& Schunn, 2009). Thus, the greatest advantage of receiving peer feedback, according to Kim (2015), is that students continually increase their understanding of how their written works are readable and acceptable from the reader's viewpoint.

In the meantime, the peer feedback emphasizes along with the inter-raters' preference through its rubric criteria, which needed more detailed scrutiny, conciseness, and comprehension on the rubric measurements, such as analytic rubric and checklist instruments. This emphasis, according to Lin and Chien (2009); Ciftci and Kocoglu (2012), has improved students' analysis skills, assisted them to raise confidence and language skills, and encouraged them to focus on ideas development. So far, this research contributes to meaningfulness as alternative feedback for either assessment for learning or assessment of learning. The supervision responsibly needs some criteria of the participation, punctuation, honesty, ideas, creativity, commitment, and maturation as shown by members in each group. This research shows the empirical evidence in which peer feedback reflects students' collaborative writing skills. The considerable reason supports an exchange of conventional learning into the constructivist learning model.

\section{CONCLUSIONS}

This collaborative writing's peer feedback corresponds with the pre- and post tests increase of the recount, narrative, and descriptive paragraphs. The results show improvement through each mean of these genre paragraphs. The leverage of the recount increases up to 2,75 points, 2,77 points for the narrative, and 3,49 points for the descriptive paragraphs. This means that pre- and post-tests achievements definitely influence collaborative writing practices. Based on the classroom experience, both experimental and control groups perceive that this peer feedback practice aims at assisting them to address collaborative writing skills.

The feedback directly contributes the individual students' writing skills in content, coherence, cohesion, punctuation, and grammar, whereas non-cognitive achievement constructs the social skills, such as involving negotiation and verbal communication skills, giving, and accepting criticism skills naturally. These lead to problem-solving competence, as well as being aware of more sustainable alignment, elaboration, and development procedure increase during the collaborative writing activity.

In further, the peer feedback foremost emphasizes on the formative assessment patterns to evaluate the processes and outputs of students' collaborative writing skills, to assess the collaborative writing's pre- and post-tests, and to understand and use the problem-solving procedure through the inter- and/or intra-group. The group members participate in the peer feedback practice since this feedback variously conducts students' learning behavior in the classroom. Students' writing skills can be supervised by the learning coaching mechanism. The peer feedback conditionally becomes the substitute for the conventional assessment practices, in which it has feasibility, adaptability, and availability contribution.

However, the research implication upon this peer feedback conditionally takes a longer preparation and reflection to gain better practice and output through the collaborative writing's assessment for the learning process. Due to its limitation, this research is also aware of being constant when the effectiveness of both practice and output become the target since the third-semester students' familiarity, and knowledge on using the writing rubric have not been appropriate yet. Last but not least, the readability of the modified and applicable rubric demonstrated in the collaborative writing's feedback instruments can be continually developed in accordance with the need analysis of the formative assessment in both guided and academic writing in the future research.

\section{REFERENCES}

Ahangari, S., \& Babapour, M. (2015). The effect of selfcorrection and peer-correction on EFL learners' writing accuracy improvement across proficiency. Journal of Language Teaching Methods, 5(2), 465473.

Altstaedter, L. L., \& Doolittle, P. (2014). Students' perceptions of peer feedback. Argentinian Journal of Applied Linguistics, 2(2), 60-76.

Arslan, R. Ş. (2014). Integrating feedback into perspective English language teacher's writing process via blogs and portfolios. The Turkish Online Journal Education Technology (TOJET), 13(1), 131-150.

Arum, R., \& Roksa, J. (2011). Academically adrift: Limited learning on college campuses. Chicago: University of Chicago Press.

Bamberger, P. A., Erev, I., Kimmel, M., \& Oref-Chen, T. (2005). Peer assessment, individual performance, and contribution to group processes: The impact of rater anonymity. Group \& Organization Management, 30(4), 344-377. https://doi. org/10.1177/1059601104267619.

Bloxham, S., \& Boyd, P. (2007). Developing effective assessment in higher education: A practical guide. Berkshire: Open University Press.

Chen, C. H., Chung, M. Y., \& Wu, W. V. (2013). The effects of faded prompts and feedback on college students' reflective writing skills. Asia-Pacific Educational Research, 22(4), 571-583.

Chen, Y. L., Liu, E. Z. F., Shih, R. C., Wu, C. T., \& Yuan, S. M. (2011). Use of peer feedback to enhance elementary students' writing through blogging. British Journal of Educational Technology, 42(1), 1-4. doi:10.1111/j.1467-8535.2010.01139.x.

Ciftci, H., \& Kocoglu, Z. (2012). Effects of peer e-feedback on Turkish EFL students' writing performance. Journal of Education Computing Research, 46(1), 61-84. https://doi.org/10.2190/EC.46.1.c.

Comer, D. K., Clark, C. R, \& Canelas, D. A. (2014). Writing to learn and learning to write across the disciplines: Peer-to-peer writing in introductory-level MOOCs. The International Review of Research in Open and Distance Learning, 15(5), 26-82.

Creswell, J. W. (2005). Educational research: Planning, conducting, and evaluating quantitative and qualitative research. New York: Pearson Education, Inc.

Ekşı̆, G. Y. (2012). Peer review versus teacher feedback in process writing: How effective. International Journal of Applied Educational Studies, 13(1), 3348.

Ferris, D. R. (1997). The influence of teacher commentary 
on student revision. TESOL Quarterly, 31(2), 315339. https://doi.org/10.2307/3588049.

Ferris, D. R., \& Hedgcock, J. S. (2005). Teaching ESL composition: Purpose, process, and practice $\left(2^{\text {nd }}\right.$ Ed.). New Jersey: Lawrence Erlbaum Associates, Inc.

Gan, M. J. S., \& Hattie, J. (2014). Prompting secondary students' use of criteria, feedback specificity and feedback levels during an investigative task. Instructional Science, 42(6), 861-878. https://doi. org/10.1007/sll251-014-9319-4.

Gardner, J. (2006). Assessment and learning. In Assessment and Learning: An Introduction (pp. 1-25). London: SAGE Publications Ltd.

Ghani, M., \& Asgher, T. (2012). Effects of teacher and peer feedback on students' writing at secondary level. Journal of Educational Research, 15(2), 84-97.

Gielen, S., Tops, L., Dochya, F., Onghena, P., \& Smeets, S. (2010). A comparative study of peer and teacher feedback and of various peer feedback forms in a secondary school writing curriculum. British Educational Research Journal, 36(1), 143-162. https://doi.org/http://doi. org/10.1080/01411920902894070.

Guasch, T., Espasa, A., Alvarez, I. B., \& Kirschner, P. A. (2013). Effects of feedback on collaborative writing in an online learning environment. Distance Education, 34(3), 324-338. https://doi.org/10.1080/ 01587919.2013 .835772$.

Hu, G., \& Lam, S. T. E. (2010). Issues of cultural appropriateness and pedagogical efficacy: Exploring peer review in a second language writing class. Instructional Science, 38(4), 371-394. https://doi. org/10.1007/s11251-008-9086-1.

Jiang, J., \& Yu, Y. (2014). The effectiveness of internetbased peer feedback training on Chinese EFL college students' writing proficiency. 34 International Journal of Information and Communication Technology Education, 10(3), 34-46. https://doi. org/10.4018/ijicte.2014070103.

Kaufman, J. H., \& Schunn, C. D. (2011). Students' perceptions about peer assessment for writing: Their origin and impact on revision work. Instructional Science, 39(3), 387-406. https://doi.org/10.1007/ s11251-010-9133-6.

Khorasani, M. R., \& Sadzadeh, A. (2015). The effect of direct and peer feedback on accuracy of EFL learners' written performance. Modern Journal of Language Teaching Methods, 5(2), 296-308.

Kim, S. H. (2015). Review in the writers' workshop. The Reading Teacher, 68(8), 599-603. https://doi.org/ doi.org/10.1002/trtr.1358.

Lai, Y. (2010). Which do students prefer to evaluate their essays: Peers or computer program. British Journal of Educational Technology, 41(3), 432-454. https:// doi.org/10.1111/j.1467-8535.2009.00959.x.

Lei, Z. (2017). Salience of student written feedback by peerrevision in EFL writing class. English Language Teaching, 10(12), 151-157. https://doi.org/10.5539/ elt.v10n12p151.

Lenters, K., \& Grant, K. (2016). Feedback loops: Assembling student editors, stories, and devices for multimodal peer feedback. Language Arts, 93(3), 185-199.

Leydon, J., Wilson, K., \& Boyd, C. (2014). Improving student writing abilities in geography: Examining the benefits of criterion-based assessment and detailed feedback. Journal of Geography, 113(4), 151-159. https://doi.org/10.1080/00221341.2013.869245.

Lin, H., \& Chien, P. (2009). An investigation into effectiveness of peer feedback. Journal of Applied Foreign Languages Fortune Institute of Technology, 3, 79-87.

Lin, W. C., \& Yang, S. C. (2011). Exploring students' perceptions of integrating Wiki technology and peer feedback into English writing courses. English Teaching: Practice and Critique, 10(2), 88-103.

Liou, H. C., \& Peng, Z. Y. (2009). Training effectson computer-mediated peer review. System, 37(3), 514 525. https://doi.org/10.1016/j.system.2009.01.005.

Liu, M., \& Chai, Y. (2009). Attitudes towards peer review and reaction to peer feedback in Chinese EFL writing classrooms. TESL Reporter, 42(1), 33-51.

McConlogue, T. (2012). But is it fair? Developing students' understanding of grading complex written work through peer assessment. Assessment \& Evaluation in Higher Education, 37(1), 113-123. https://doi.org /10.1080/02602938.2010.515010.

McGrath, A. L., Taylor, A., \& Pychyl, T. A. (2011). Writing helpful feedback: The influence of feedback type on students' perceptions and writing performance. The Canadian Journal for the Scholarship of Teaching and Learning, 2(2), 1-14. https://doi.org/10.5206/ cjsotl-rcacea.2011.2.5.

Mooney, C. (2004). Beware sound science, its doublespeak for trouble. Retrieved from https://www. washingtonpost.com/archive/opinions/2004/02/29/ beware-sound-science-its-doublespeak-for-trouble.

Nelson, M. M., \& Schunn, C. D. (2009). The nature of feedback: How different types of peer feedback affect writing performance. Instructional Science, 37(4), 375-401. https://doi.org/10.1007/s11251008-9053-x.

Nguyen, P. T. T. (2012). Peer feedback on second language writing through blogs: The case of a Vietnamese EFL classroom. International Journal of ComputerAssisted Language Learning and Teaching, 2(1), 13-23. https://doi.org/10.4018/ijcallt.2012010102.

Pappamihiel, N. E., Nishimata, T., \& Mihai, F. (2008). Timed writing and adult English-language learners: An investigation of first language use in invention strategies. Journal of Adolescent \& Adult Literacy, 51(5), 386-394.

Patchan, M. M., Hawk, B., Stevens, C. A., \& Schunn, C. D. (2013). The effects of skill diversity on commenting and revisions. Instructional Science, 41(2), 381-405. http://dx.doi.org/10.1007/s11251-012-9236-3.

Philpott, J. (2009). Captivating your class: Effective teaching skills. London: Continuum.

Prastika, W., Setiawati, E. E. D., \& Sumekto, D. R. (2018). Analyzing the eleventh-year-students' descriptive writing skills documented in the academic year of 2017-2018. English Focus: Journal of English Language Education, 1(2), 108-118.

Roberts, T. J., \& Shambrook, J. (2012). Academic excellence: A commentary and reflections on the inherent value of peer review. Journal of Research Administration, 43(1), 33-38.

Ruegg, R. (2014). The effect of assessment of peer feedback on the quantity and quality of feedback given. Papers in Language Testing and Assessment, 3(1), 24-43.

Strijbos, J. W., Narciss, S., \& Dünnebier, K. (2010). Peer feedback content and sender's competence level in 
academic writing revision tasks: Are they critical for feedback perceptions and efficiency? Learning and Instruction, 20(4), 291-303. https://doi. org/10.1016/j.learninstruc.2009.08.008.

Sumekto, D. R. (2017). The effectiveness of pre-service English teachers' collaborative genre based writing feedback. Lingua Cultura, 11(1), 31-38. https://doi. org/10.21512/lc.v11i1.1595.

Sumekto, D. R., \& Setyawati, H. (2018). Students' descriptive writing performance: The analytic scoring assessment usage. Cakrawala Pendidikan, 37(3), 413-425. https://doi.org/10.21831/cp.v38i3.20033.

Taylor, S. M. (2014). Can peer review help Johnny write better? The Journal of Adventist Education, 76, 4246.

Topping, K. J. (2009). Peer assessment. Theory Into Practice, 48(1), 20-27. https://doi. org/10.1080/00405840802577569.

Tsui, A. B. M., \& Ng, M. (2000). Do secondary L2 writers benefit from peer comments? Journal of Second Language Writing, 9(2), 147-170. https://doi. org/10.1016/S1060-3743(00)00022-9.
Van Popta, E., Kral, M., Camp, G., Martens, R. L., Simons, P. R. J. (2017). Exploring the value of peer feedback in online learning for the provider. Educational Research Review, 20, 24-34. https://doi. org/10.1016/j.edurev.2016.10.003.

Wakabayashi, R. (2013). The effects of the peer feedback process on reviewers' own writing. English Language Teaching, 6(9), 177-192. https://doi.org/ doi.org/10.5539/elt.v6n9p177.

Yu, S. (2015). What factors shape the collaborative patternof group interaction during peer feedback inthe L2 writing classroom? Revista Española de Lingüística Aplicada, 28(2), 618-640. https://doi.org/10.1075/ resla.28.2.10yu.

Yu, S., Lee, I., \& Mak, P. (2016). Revisiting Chinese cultural issues in peer feedback in EFL writing: Insights from a multiple case study. Asia-Pacific Educational Research, 25(2), 295-304. https://doi.org/10.1007/ s40299-015-0262-1. 